\title{
BIOCHEMICAL PARAMETERS OF BLOOD SERUM IN YOUNG PIGS UNDER FEEDING OF "LG-MAX" FEED ADDITIVE
}

S. A. TKACHUK, Doctor of Veterinary Sciences, Professor, Department of Veterinary Hygiene named after Professor A. K. Skorokhodko https://orcid.org/0000-0002-6923-1793

National University of Life and Environmental Sciences of Ukraine, Kyiv, Ukraine E-mail: ohdin@ukr.net

L. V. TКАСНYK, Graduate Student, Department of Veterinary Hygiene named after Professor A. K. Skorokhodko

National University of Life and Environmental Sciences of Ukraine, Kyiv, Ukraine

E-mail: tkluz78@gmail.com

V. P. LYASOTA, Doctor of Veterinary Sciences, Professor,

Department of Veterinary and Sanitary Examination, Hygiene of Livestock

Products and Pathological Anatomy named after Y. S. Zahaievskyi https://orcid.org/0000-0002-2442-2174

Bila Tserkva, National Agrarian University, Bila Tserkva, Ukraine

E-mail: lyasota777@gmail.com

\begin{abstract}
The acquired domestic and foreign experience of pig breeding development, an increase of animal productivity, and reduction of pork cost by 65-70\% and more is determined by scientifically substantiated feeding. At the same time, the biochemical parameters of pig blood serum can be used to assess the functional state of the body and predict animal productivity and meat quality.

The purpose of the study was to determine the morphological and biochemical blood parameters in young pigs with the inclusion of LG-Max and Sel-Plex feed additives to the main diet.

When using in pig feeding LG-MAX feed additive at a dose of $4.0 \mathrm{~g} /$ day, the blood biochemical parameters in pigs of the experimental groups compared with the control were within physiological limits according to the age of the animals.

At the same time, during the experimental period it was found that the biochemical parameters in blood serum of pigs of the experimental group compared to the control of the appropriate age are in the following dynamics: in 120-day-old pigs, significantly increases the content of total protein, the concentration of $\gamma$-globulins and aspartate aminotransferase, decreases the content of albumin, glucose, creatinine, cholesterol, and alkaline phosphatase; in 155-day-old pigs, the concentration of $\gamma$-globulins and the albumin/globulin ratio significantly increases and the urea, calcium, and chloride content increases; cholesterol and iron levels were significantly lower.
\end{abstract}

Keywords: biochemical parameters, blood serum, LG-MAX feed additive 


\section{Introduction}

The organization of full-fledged animal feeding contributes to the achievement of an intensive type of pig breeding development and the formation of sufficient volumes of supply of high-quality and safe pig products. The acquired domestic and foreign experience in the development of pig breeding, increasing animal productivity, and reducing the cost of pork by $65-70 \%$ or more is determined by scientifically substantiated feeding (Ibatullin, 2017).

Today, it remains important to create conditions for improving the consumption and efficiency of feed use, obtaining quality food, which can be ensured by a high level of balanced feeding with the use of various feed additives. At this stage of feed industry development, a large number of feed additives are used in animal feeding (Polishchuk et al., 2010).

Among the variety of feed additives are those that contain polyunsaturated fatty acids (PUFAs). It is known that PUFAs play an important role in the functioning of a living organism, in particular humans. Currently, there are several classes of fatty acids that are part of dietary fats: saturated (myristic, palmitic, stearic, and others), monounsaturated (omega-oleic), polyunsaturated (omega-arachidonic, linoleic, omega 3-eicosapentaenoic, and docosahexaenoic). Indispensable (essential) Omega-6 and Omega-3 PUFAs are almost not synthesized in the human body but are received with food. For normal human life, Omega-3 PUFAs should be received not only in sufficient quantities but also in a balanced ratio with Omega-6 PUFAs (ideal Omega-6/3 ratio 4:1) (Sirenko et al., 2012). It is metabolites that determine the physiological effects of PUFAs in the human body.
By consuming in sufficient quantities, Omega-3 PUFAs replace Omega-6 in membrane phospholipids and numerous metabolic reactions. Eicosanoids formed from Omega-6 and Omega-3 PUFAs have opposite properties.

However, peroxidation of PUFAs into low-density lipoproteins plays an important role in the pathogenesis of atherogenesis (Jenkins et al., 2006). Intermediate metabolites of biohydrogenation of linoleic and linolenic acids are biologically active compounds that have a regulatory effect, prevent the occurrence of cancer and cardiovascular disease in humans (Kilian et al., 2009).

\section{Analysis of recent researches and publications}

It is known that the biochemical composition of blood can serve as an indicator of the functional state of the body and be used to predict animal productivity and meat quality. The circulatory system provides two important mechanisms of natural resistance: cellular and nonspecific humoral protection. The state of humoral mechanisms of natural resistance is evidenced by the following blood parameters: red blood cell count, hemoglobin concentration, white blood cell count, leukocyte blood formula, the concentration of total protein and its fractions (including albumins, $\alpha-, \beta$ - and $\gamma$-globulins). The morphological and biochemical blood composition has a significant impact on the intensity of metabolic and redox processes in pigs, and which might indicate the intensity of metabolism that, in turn, affects the level of their productivity. Metabolism is influenced by genotype, gender, age, level of animal feeding, etc. (Strizhak et al., 2014).

A number of scientists have shown that the assessment of morphological and 
biochemical blood parameters in pigs after application of probiotics (Kluczek, 2006), mineral feed additives (Kucheriavyi et al., 2017), biologically active additives (Grushanska et al., 2017), enzyme preparations (Kovalenko et al., 2010; Bankovska et al., 2011; Hutsol, 2013), homogenized feed (Derzhgovsky, 2008) is a necessary study to establish the scientific evidence of the effects on the body of additives used in pig feeding.

In other studies, researchers have shown a correlation between the quality of muscle tissue and the assessment of the biochemical blood parameters in pigs of different categories. Thus, it was found that young pigs of the "low quality" meat category in terms of moisture retention, tenderness, and intramuscular fat content are characterized by a higher content of total protein $(0.67-6.73 \mathrm{~g} / \mathrm{L})$, the activity of aspartate aminotransferase $(0.06-0.31 \mathrm{mmol} / \mathrm{h} / \mathrm{L})$ and alkaline phosphatase (4.89-47.56 IU/L) in blood serum compared to peers of the "high quality" category. Significant correlation coefficients were established by pairs of characteristics: "tenderness $\times$ cholesterol content" $(r=0.420 \pm 0.1892, t r=2.22)$ and "color intensity, extinction units $x$ $1000 \times$ alkaline phosphatase activity" $(\mathrm{r}=-0.483 \pm 0.1826, \mathrm{tr}=2.64)($ Khalak et al., 2017). In this context, the author proved that in young pigs at the age of 6 months albumin concentration ranged from 32.06 to $35.68 \mathrm{~g} / \mathrm{L}$ with the best values of moisture retention, tenderness, fat content, and color intensity of muscle tissue from longissimus dorsi muscle.

According to the indicators of albumin/globulin ratio in blood serum, it is possible to determine the biological characteristics of pigs of different genotypes in different physiological conditions. Thus, it has been proven that the most precocious animals were from combinations of local sows and local sows with Duroc boars (Kodak, 2011).

Purpose - to determine the morphological and biochemical blood parameters in young pigs under inclusion of LG-Max and Sel-Plex feed additives to the main diet.

\section{Materials and methods of research}

Pigs were fed with feed additives as a premix added to the feed to meet the needs of pigs in Omega-3 PUFAs (a daily requirement for Omega-3 in pigs is 672 $\mathrm{mg}$; the experimental feed additive contains $353 \mathrm{mg}$ of Omega-3PUFAs per $1 \mathrm{~g}$ ).

Based on this, a scheme of the scientific and economic experiment was built. After a 15-day equalization period, 4 groups of analogs from young pigs (5 animals in the control and experimental groups) by origin, age, and live weight were formed. The animals were kept in pens with 5 pigs in each. The experimental groups were formed from wild boars - young castrated male pigs.

According to the experimental scheme, the pigs of the control group were fed the main diet, the animals of the experimental groups - main diet + different amounts of feed additives. Thus, pigs of the 1 st experimental group were fed $2.0 \mathrm{~g} / \mathrm{day}$ of LG-MAX supplemented to the main diet, 2nd experimental group $-4.0 \mathrm{~g} /$ day of LG-MAX, and 3rd experimental group $-2.0 \mathrm{~g} /$ day of LG-MAX and Sel-Plex $(0.5 \mathrm{mg} / \mathrm{kg})$ according to the registration certificate. This article presents the results of a biochemical study of blood serum in pigs of the 2nd experimental ( $\mathrm{E}_{2}$ ) group (4.0 $\mathrm{g}$ /day of LG-MAX feed additive).

Determination of morphological and biochemical blood parameters in young pigs (45-, 120- and 155-day-old) was per- 
formed after a 15-day equalization period. To do this, blood samples were taken from clinically healthy pigs. Blood was taken from the marginal ear vein in the morning before feeding (Tkachyk et al., 2019).

For morphological studies, blood was collected in special tubes with Trilon B, and for biochemical - whole blood, which was defended and centrifuged to obtain serum.

The count of white blood cells (WBC) and red blood cells (RBC), hemoglobin content $(\mathrm{Hb})$ were determined on an automatic hematology analyzer PCE 90 Vet.

Serum biochemical parameters were determined using an automatic biochemical analyzer GBG ChemWell 2910 (USA) and using a test system Global Scientific (USA).

\section{Results of the research and their discussion}

Table 1 shows the blood biochemical analysis in pigs under feed supplementation with LG-MAX feed additive (4.0 g/day).

According to the obtained results (Table 1) for 45-day-old pigs of the experimental group, the concentration of $\beta$-globulins in blood serum was significantly lower by $1.0 \%(\mathrm{P}<0.05)$, urea - by $0.44 \%(\mathrm{P}<0.01)$, phosphorus - by $0.19 \%(\mathrm{P}<0.05)$, and aspartate aminotransferase (AST) activity - by $12.2 \%$ $(\mathrm{P}<0.01)$ compared with the control.

An increase in $\gamma$-globulin concentration in blood serum compared to that in pigs of the control group indicates the stabilization of immune defense processes.

In general, globulins are a heterogeneous mixture of protein molecules, in which $\alpha$-, $\beta$ - and $\gamma$-globulins are secreted. Each of these fractions contains specific proteins that perform certain biochemical functions. The composition of this fraction includes transferrin, hemopexin, $\beta 2$-microglobulin, low-density lipoproteins, components of the complement system (C3). The physiological norm for globulin concentration in blood serum of pigs is from 50 to $65 \%$.

Important for the body of animals are blood $\gamma$-globulins, which are the material for the construction of antibodies, as well as $\alpha-, \beta$-globulins, which bind such complex compounds as carbohydrates, cholesterol, phosphatase, vitamins, and hormones.

To study the response to changes in animals caused by disease or stress, the albumin/globulin ratio is determined.

Scientists have proved that in young pigs of large white breed of Hungarian selection, the albumin/globulin ratio was 0.5 for the entire study period and had the smallest deviations from the mean, which indicates that for animals of this genotype albumin/globulin ratio is the most stable value and indicates their sufficiently high resistance and adaptability (Kyslynska, 2012).

On the 120th day of the experiment, the content of total protein in blood serum of pigs of the experimental group was significantly higher by $9.48 \%(\mathrm{P}<$ $0.001), \gamma$-globulins - by $2.0 \%(\mathrm{P}<0.05)$, AST activity- by $3.0 \%(\mathrm{P}<0,05)$ compared with the control. Instead, the albumin content was significantly lower by $1.8 \%(\mathrm{P}<0.05)$, glucose - by $0.34 \%(\mathrm{P}<$ $0.05)$, creatinine - by $43.0 \%(\mathrm{P}<0.001)$, cholesterol - by $0.54 \%(\mathrm{P}<0.001)$, and alkaline phosphatase - by $34.6 \%$ (P < 0.001) compared with the control.

The increase in total protein content can be explained by the fact that blood proteins are able to provide the body with the disease resistance, building muscle tissue. Intensively growing animals have higher levels of total protein (Vognivenko et al., 2015). 
It is known that albumins are simple globular proteins that play an important role in the body, namely: involved in maintaining oncotic blood pressure, therefore, when the concentration of albumin is less than $30 \mathrm{~g} / \mathrm{L}$, the oncotic pressure decreases and edema occurs. Albumins bind and transport free fatty acids. This binding reduces the concentration of physiologically active free fatty acids by 10,000 times. Therefore, a decrease in the amount of albumin may be one of the reasons for the development of fatty infiltration of the liver. Perform accumulative and plastic functions. A significant decrease in the concentration of albumin (up to $5 \mathrm{~g} / \mathrm{L}$ ) is possible for kidney disease with severe nephrotic syndrome.

One of the important components of protein metabolism in blood serum are transamination enzymes, especially aspartate and alanine aminotransferase. These enzymes are catalysts for the amine group transfer reaction between amino and keto acids resulting in the formation of new amino acids, i.e. protein synthesis. The higher their concentration, the higher the activity of a particular metabolic process, the more active the enzyme, the more intense are the metabolic processes in the body (Voloshchuk, 2018).

Before slaughter of pigs on the 155th day of the experiment, the concentration of $\gamma$-globulins significantly increased by $2.8 \%(\mathrm{P}<0.05)$ and $\mathrm{Alb} / \mathrm{Glo}$ ratio - by $0.22 \%(\mathrm{P}<0.05)$. However, the content of urea was significantly higher by $1.24 \%(\mathrm{P}<0.01)$, calcium - by 0.22 $(\mathrm{P}<0.05)$, and chloride - by $2.6 \%$ $(\mathrm{P}<0.05)$ compared with the control. At the same time, the cholesterol content was significantly lower by $0.66(\mathrm{P}<0.01)$ and iron - by $2.94 \%(\mathrm{P}<0.001)$ compared with the control.
It is known that urea is the end product of protein metabolism, the main component of residual nitrogen in mammalian blood. The concentration of urea depends on the intensity of its synthesis and excretion, so it is an important test to assess both the function of the liver where it is synthesized and the kidneys through which it is excreted (Novikova, 2013). An important indicator of the state of metabolic processes, animal growth, ensuring the synthesis of biologically active compounds, the ability to bind toxic substances and disinfect them, participation in the formation of bile acids, vitamin $\mathrm{D}$, hormones, and gonads, is cholesterol.

It is known that unsaturated fatty acids affect the normalization of blood vessel walls, increasing their elasticity and reducing permeability, as well as promote the rapid conversion of cholesterol into folic acid and their excretion from the body. Unsaturated fatty acids have been linked to cholesterol metabolism.

The results obtained for a significant decrease in cholesterol level in blood serum of pigs of all experimental groups may indicate an increase in the formation of muscle tissue and a decrease in the adipose tissue when used in the feeding of LG-MAX and Sel-Plex organic feed additives. It is also possible that the regulation of lipid metabolism is due to the content of Omega-3 PUFA in LG-MAX feed additive. Also, it may be similar to the use of fermented feed in pigs (Zinoviev, 2011) and the beginning of lipid deposition in the fat depot, and, therefore, they are found in smaller quantities in blood serum of these animals (Vikulina, 2008).

According to other studied indicators (Table 1), there is a tendency to change between the experimental group and the control. 


\section{Biochemical parameters of pig blood serum under feed supplementation with LG-MAX feed additive (4.0 g/day), $M \pm m, n=5$}

\begin{tabular}{|c|c|c|c|c|c|c|}
\hline \multirow[b]{2}{*}{ Parameter } & \multicolumn{6}{|c|}{ Group } \\
\hline & $\begin{array}{l}\text { Control } \\
45 \text { days }\end{array}$ & $\begin{array}{c}\mathrm{E}_{2} \\
45 \text { days }\end{array}$ & $\begin{array}{c}\text { Control } \\
120 \text { days }\end{array}$ & $\begin{array}{c}\mathrm{E}_{2} \\
120 \text { days }\end{array}$ & $\begin{array}{c}\text { Control } \\
155 \text { days }\end{array}$ & $\begin{array}{c}\mathrm{E} \\
155 \text { days }\end{array}$ \\
\hline $\begin{array}{l}\text { Total protein, } \\
\mathrm{g} / \mathrm{L}\end{array}$ & $51.24 \pm 0.80$ & $51.94 \pm 1.44$ & $73.00 \pm 0.16$ & $79.92 \pm 1.05 * * *$ & $76.80 \pm 0.81$ & $77.44 \pm 0.79$ \\
\hline Albumin, $\%$ & $59.40 \pm 1.08$ & $60.20 \pm 0.86$ & $2.60 \pm 0.40$ & $50.80 \pm 0.49 *$ & $48.60 \pm 0.51$ & $50.40 \pm 0.93$ \\
\hline Globulins, \% & $41.20 \pm 0.86$ & $39.80 \pm 0.86$ & $50.0 \pm 1.70$ & $50.00 \pm 0.63$ & $54.40 \pm 1.21$ & $52.00 \pm 0.89$ \\
\hline$\alpha 1$-globulins & $3.60 \pm 0.24$ & $3.40 \pm 0.24$ & $3.40 \pm 0.40$ & $3.40 \pm 0.24$ & $3.80 \pm 0.37$ & $3.20 \pm 0.20$ \\
\hline a2-globulins & $14.40 \pm 0.24$ & $15.20 \pm 0.37$ & $17.40 \pm 0.51$ & $15.20 \pm 1.07$ & $19.40 \pm 1.50$ & $16.60 \pm 1.03$ \\
\hline$\beta$-globulins & $10.60 \pm 0.24$ & $9.60 \pm 0.24 *$ & $16.60 \pm 0.51$ & $16.80 \pm 0.58$ & $19.20 \pm 0.86$ & $18.00 \pm 0.45$ \\
\hline$\gamma$-globulins & 10.80 & $10.40 \pm$ & 51 & $11.60 \pm 0.68$ & 8.2 & $11.00 \pm 0.89^{*}$ \\
\hline $\begin{array}{l}\mathrm{Alb} / \mathrm{Glo} \\
\text { ratio }\end{array}$ & $1.54 \pm 0.03$ & $1.59 \pm 0.03$ & $1.05 \pm 0.23$ & $1.04 \pm 0.02$ & $0.89 \pm 0.02$ & $0.96 \pm 0.08$ \\
\hline $\begin{array}{l}\text { Glucose, } \\
\mathrm{mmol} / \mathrm{L}\end{array}$ & $6.26 \pm 0.05$ & $6.34 \pm 0.20$ & $6.94 \pm 0.09$ & $6.60 \pm 0.09^{*}$ & $6.46 \pm 0.14$ & $6.44 \pm 0.14$ \\
\hline ALT, U/L & $.00 \pm 0.71$ & $40.40 \pm 0.51$ & $6.20 \pm 0.37$ & $47.00 \pm 2.17$ & $46.80 \pm 1.39$ & $47.20 \pm 1.77$ \\
\hline AST, U/L & $76.60 \pm 1.47$ & $64.40 \pm 2.01 * *$ & $66.40 \pm 0.51$ & $68.40 \pm 0.51^{*}$ & $63.60 \pm 1.81$ & $67.00 \pm 0.84$ \\
\hline $\begin{array}{l}\text { Urea, } \\
\mathrm{mmol} / \mathrm{L}\end{array}$ & $2.72 \pm 0.06$ & $\begin{array}{l}2.28 \pm \\
0.09^{* *}\end{array}$ & $4.68 \pm 0.24$ & $4.56 \pm 0.22$ & $4.72 \pm 0.12$ & $\begin{array}{l}5.96 \pm \\
0.25^{* *}\end{array}$ \\
\hline $\begin{array}{l}\text { Creatinin, } \\
\mu \mathrm{mol} / \mathrm{L}\end{array}$ & $\begin{array}{c}102.20 \pm \\
3.75\end{array}$ & $99.20 \pm 5.70$ & $116.0 \pm 4.51$ & $73.00 \pm 1.41 * * *$ & $\begin{array}{c}162.00 \pm \\
5.13\end{array}$ & $\begin{array}{c}164.40 \pm \\
2.86\end{array}$ \\
\hline $\begin{array}{l}\text { Cholesterol, } \\
\mathrm{mmol} / \mathrm{L}\end{array}$ & $2.54 \pm 0.16$ & $2.58 \pm 0.15$ & $2.94 \pm 0.07$ & $2.40 \pm 0.071^{* * *}$ & $2.94 \pm 0.13$ & $\begin{array}{l}2.28 \pm \\
0.09 * *\end{array}$ \\
\hline $\begin{array}{l}\text { Alkaline } \\
\text { phosphatase, } \\
\text { U/L }\end{array}$ & $\begin{array}{c}167.40 \pm \\
2.09\end{array}$ & $\begin{array}{c}172.00 \pm \\
1.89\end{array}$ & $\begin{array}{c}165.80 \pm \\
1.94\end{array}$ & $\begin{array}{l}131.20 \pm \\
2,22 * * *\end{array}$ & $\begin{array}{c}155.20 \pm \\
3.92\end{array}$ & $153.0 \pm 1.70$ \\
\hline $\begin{array}{l}\text { Bilirubin, } \\
\mathrm{mmol} / \mathrm{L}\end{array}$ & $3.80 \pm 0.49$ & $4.00 \pm 0.71$ & $5.60 \pm 0.24$ & $4.80 \pm 0.37$ & $6.00 \pm 0.71$ & $7.00 \pm 0.45$ \\
\hline \begin{tabular}{|l|} 
Amylase, \\
$\mathrm{U} / \mathrm{L}$
\end{tabular} & $\begin{array}{c}2145.20 \pm \\
194.80\end{array}$ & $\begin{array}{c}1914.40 \pm \\
97.94\end{array}$ & $\begin{array}{c}845.40 \pm \\
30.24 \\
\end{array}$ & $783.20 \pm 30.86$ & $\begin{array}{c}797.80 \pm \\
36.23 \\
\end{array}$ & $\begin{array}{c}857.60 \pm \\
15.03 \\
\end{array}$ \\
\hline $\begin{array}{l}\text { Calcium, } \\
\mathrm{mmol} / \mathrm{L}\end{array}$ & $2.45 \pm 0.02$ & $2.41 \pm 0.04$ & $2.50=$ & $2.48 \pm 0.03$ & $2.42 \pm 0.01$ & $2.64 \pm 0.07^{*}$ \\
\hline $\begin{array}{l}\text { Phosphorus, } \\
\mathrm{mmol} / \mathrm{L}\end{array}$ & $1.72 \pm 0.07$ & $1.53 \pm 0.03^{*}$ & $2.00 \pm 0.07$ & $2.20 \pm 0.07$ & $2.42 \pm 0.12$ & $2.14 \pm 0.07$ \\
\hline $\begin{array}{l}\text { Potassium, } \\
\mathrm{mmol} / \mathrm{L}\end{array}$ & $4.08 \pm 0.18$ & $4.14 \pm 0.14$ & $4.96 \pm 0.07$ & $4.84 \pm 0.07$ & $5.18 \pm 0.08$ & $5.22 \pm 0.07$ \\
\hline \begin{tabular}{|l|} 
Iron, \\
$\mathrm{mol} / \mathrm{L}$
\end{tabular} & $25.70 \pm 0.60$ & $23.80 \pm 0.97$ & $24.48 \pm 0.78$ & $26.50 \pm 0.57$ & $28.08 \pm 0.01$ & $\begin{array}{l}25.14 \pm \\
0.58^{* * * *}\end{array}$ \\
\hline $\begin{array}{l}\text { Sodium, } \\
\mathrm{mmol} / \mathrm{L}\end{array}$ & $\begin{array}{c}142.20 \pm \\
1.07\end{array}$ & $\begin{array}{c}145.40 \pm \\
1.21\end{array}$ & $\begin{array}{c}145.20 \pm \\
0.86\end{array}$ & $147.00 \pm 0.71$ & $\begin{array}{c}147.80 \pm \\
1.36\end{array}$ & $\begin{array}{c}145.00 \pm \\
0.84\end{array}$ \\
\hline \begin{tabular}{|l} 
Chlorides, \\
$\mathrm{mmol} / \mathrm{L}$
\end{tabular} & $99.00 \pm 1.09$ & $99.00 \pm 1.30$ & $\begin{array}{c}104.80 \pm \\
1.39 \\
\end{array}$ & $107.00 \pm 0.71$ & $\begin{array}{c}103.00 \pm \\
0.71 \\
\end{array}$ & $\begin{array}{c}105.60 \pm \\
0.51 * \\
\end{array}$ \\
\hline $\begin{array}{l}\text { Magnesium, } \\
\mathrm{mmol} / \mathrm{L}\end{array}$ & $1.22 \pm 0.11$ & $1.30 \pm 0.10$ & $1.54 \pm 0.12$ & $1.32 \pm 0.12$ & $1.88 \pm 0.09$ & $2.00 \pm 0.07$ \\
\hline
\end{tabular}

Note: $* \mathrm{P}<0.05 ; * * \mathrm{P}<0.01 ; * * * \mathrm{P}<0.001$ compared with the control of the corresponding age. 


\section{Conclusions and future perspectives}

When using in pig feeding LG-MAX feed additive in a dose of $4.0 \mathrm{~g} /$ day, the biochemical blood parameters in pigs of the experimental groups compared with the control, were within physiological limits according to the age of the animals.

At the same time, during the experimental period, it was found that the biochemical parameters in blood serum of pigs of the experimental group compared with the control of the appropriate age are in the following dynamics: in pigs aged 45 days, the concentration of $\beta$-globulins is significantly reduced and the content of aspartate aminotransferase, urea, and phosphorus is reduced; in 120-day-old pigs, significantly increases the content of total protein, the concentration of $\gamma$-globulins and aspartate aminotransferase, significantly decreases the content of albumin, glucose, creatinine, cholesterol, and alkaline phosphatase; in 155-day-old pigs, the concentration of $\gamma$-globulins and albumin/globulin ratio significantly increases and urea, calcium and chloride content increases; cholesterol and iron levels were significantly lower.

Further plans include histological examination of the liver in young pigs when feeding different amounts of this feed additive.

\section{References}

Bankovska, I. B., Bindiuh, O. A., \& Zinoviev, S. H. (2011). Yakist m'iasa svynei za umov vykorystannia fermentovanykh kormovykh dobavok [Quality of pig meat under the use of fermented feed additives]. Svynarstvo, 59, 43-49.

Derzhhovskyi, O. O. (2008). Fizyko-khimichni vlastyvosti svynyny pry vykorystanni homohenizovanoho kormu [Physico-chemical properties of pork when using homogenized feed]. Problemy zooinzhenerii ta veterynarnoi medytsyny, 16 ((41)1), 206-210.

Hrushanska, N. H., \& Kostenko, V. M. (2017).

Biokhimichni pokaznyky krovi svynomatok za profilaktyky porushen obminu mineralnykh rechovyn [Biochemical parameters of sows' blood for prevention of mineral metabolism disorders]. Naukovyi visnyk LNUVMB imeni S. Z. Gzhytskoho, 19(82), 71-76.

Hutsol, A. V. (2013). Biokhimichni pokaznyky krovi svynei pry zghodovuvanni fermentatyvnykh preparativ [Biochemical parameters of pig blood during feeding of enzymatic preparations]. Visnyk ahrarnoi nauky Prychornomor'ia, 4(2)1, 73-76.

Ibatullin, M. I. (2017). Kormozabezpechennia, yak osnova efektyvnoho svynarstva v Ukraini [Feed supply as a basis for efficient pig breeding in Ukraine]. Ekonomika ta derzhava, 10, 13-16.

Jenkins, T., \& Guire, M. Mc. (2006). Major advances in nutrition: impact on milk composition. Journal of Dairy Science, 89(4), 1302-1310.

Khalak, V. I., Hrabovska, O. S., Luchka, I. V., \& Denys, H. H. (2017). Biokhimichni pokaznyky syrovatky krovi svynei riznykh katehorii za yakisnym skladom m'iazovoi tkanyny [Biochemical parameters of serum of pigs of different categories according to the qualitative composition of muscle tissue]. Biolohiia tvaryn, 19(4), 64-72.

Kilian, M., Gregor, J., \& Heukamp, I. (2009). Early inhibition of prostaglandin synthesis by n-3 fatty acids determinates histologic severity of necrotizing pancreatitis. Pancreas, 38(4), 436-441.

Kluczek, S. (2006). Wskaźniki biochemiczne w surowicy krwi tucznikow z uwzględnieniem sytemu utrzymania i behawioryzmu socjalnego. Rozprawy, 121, 35-43.

Kodak, T. S. (2011). Hematolohichni pokaznyky krovi molodniaku svynei riznykh henotypiv [Hematological parameters of the blood of young pigs of different genotypes]. Svynarstvo, 59, 39-43. 
Kovalenko, V. F., Zinov'ev, S. G., Bindyug, A. A., \& Ban'kovskaya, I. B. (2010). Novye fermentirovannye kormovye dobavki v svinovodstve [New fermented feed additives for pig production]. Zootekhniya, 1, 18-19.

Kucheriavyi, V. P., \& Boichuk, V. M. (2017). Pokaznyky krovi vidhodivelnoho molodniaku svynei pry zghodovuvanni pro biotychnoho preparatu [Blood indicators of fattening young pigs when fed about a biotic drug]. Ahrarna nauka ta kharchovi tekhnolohii tekhnolohiia kormiv, 4(98), 34-40.

Kyslynska, A. I. (2012). Pokaznyky pryrodnoi rezystentnosti krovi molodniaku svynei velykoi biloi porody uhorskoi selektsii v period adaptatsii [Indicators of natural resistance of blood of young pigs of large white breed of Hungarian selection in the period of adaptation]. Visnyk ahrarnoi nauky Prychornomor'ia, 1, 149-155.

Novikova, N. V. (2013). Osoblyvosti biokhimichnoho skladu krovi svynei z riznoiu adaptatsiinoiu normoiu $v$ umovakh plemzavodu TOV "Fridom farm bekon" [Features of the biochemical composition of the blood of pigs with different adaptation rates in the breeding plant LLC "Freedom Farm Bacon"]. Visnyk ahrarnoi nauky Prychornomor'ia, 4(1), 143-148.

Polishchuk, A. A., \& Bulavkina, T. P. (2010). Suchasni kormovi dobavky $v$ hodivli tvaryn ta ptytsi [Modern feed additives in animal and poultry feeding].Visnyk Poltavskoi derzhavnoi ahrarnoi akademii, 2, 63-66.

Sirenko, Yu. N., \& Kushnir, S. N. (2012). Vliyanie Omega-3 polinenasyshchennyh zhirnyh kislot na funkcional'nye svojstva sosudov u bol'nyh arterial'noj gipertenzie [The effect of omega-3 polyunsaturated fatty acids on the functional properties of blood vessels in patients with arterial hypertension]. Ukraïns'kij medichnij chasopis, 4(90), 117-120.

Stryzhak, T. A., Khalina, L. V., Zakharov, V. V., \& Nahornyi, S. A. (2014). Hematolohichni pokaznyky yak osoblyvosti inter'iernoho statusu svynei u selektsiino-pleminnii roboti
[Hematological parameters as features of the interior status of pigs in breeding and breeding work]. Visnyk Kharkivskoho natsionalnoho tekhnichnoho universytetu silskoho hospodarstva imeni Petra Vasylenka, 144, 212-217.

Tkachyk, L. V., \& Tkachuk, S. A. (2019). Biokhimichni pokaznyky syrovatky krovi svynei za zastosuvannia u hodivli orhanichnoi kormovoi dobavky Lg-Max [Biochemical parameters of pig blood serum for use in feeding of organic feed additive Lg-Max]. Naukovi dopovidi NUBiP Ukrainy, 1(77). doi: 10.31548/dopovidi2019.01.026;

Vikulina, H. V. (2008). Deiaki pokaznyky obminu lipidiv syrovatky krovi porosiat riznoho viku [Some indicators of serum lipid metabolism in piglets of different ages]. Naukovyi visnyk Lvivskoho NUVMBT im. S. Z. Hzhytskoho, 10((1)(2(37)), 24-28.

Vohnivenko, L. P., Novikova, N. V., Arkhanhelska, M. V., Papakina, N. S., Kushnerenko, V. H., Lisna, T. M., \& Ferens, T. O. (2015). Zviazok mizh biokhimichnymy pokaznykamy krovi svynei riznoi stresostiikosti iz yikh vidhodivelnymy yakostiamy v umovakh plemzavodu ZAT "Fridom farm bekon" [Relationship between biochemical parameters of blood of pigs of different stress resistance with their fattening qualities in the conditions of breeding farm of CJSC "Freedom Farm Bacon"]. Svynarstvo, 5(5), 183-191.

Voloshchuk, O. V. (2018). Osoblyvosti obminu rechovyn chystoporodnoho i pomisnoho molodniaku svynei [Features of metabolism of purebred and local young pigs]. Naukovi dopovidi NUBiP Ukrainy, 1(71). Retrieved from http://journals.nubip.edu.ua/ index.php/Dopovidi/article/view/10032.

Zinoviev, S. H. (2011). Vplyv fermentovanykh kormiv na biokhimichnyi status krovi ta produktyvnist svynei [Influence of fermented feed on blood biochemical status and pig productivity]. Naukovi dopovidi NUBiP Ukrainy, 4(26). Retrieved from http://www.nbuv.gov. ua/e-journals/Nd/2011_4/11zsg.pdf 


\section{С. А. Ткачук, Л. В. Ткачик, В. П. Лясота (2021). БІОХІМІчНІ ПОКАЗНИКИ СИРОВАТКИ КРОВІ МОЛОДНЯКУ СВИНЕЙ ЗА ЗГОДОВУВАННЯ КОРМОВОЇ \\ ДОБАВКИ LG-MAX. Ukrainian Journal of Veterinary Sciences, 12(1): 14-22, \\ https://doi.org/10.31548/ujvs2021.01.002}

Анотація. Набутий вітчизняний та зарубіжний досвід розвитку свинарства, підвищення продуктивності тварин і зниження собівартості свинини на 65-70\% і більше визначається науково-обгрунтованою годівлею. Водночас, за біохімічними показниками сироватки крові свиней можна оцінити функціональний стан організму та прогнозувати їню продуктивність і якість м'яса.

Метою дослідження було визначити морфологічні та біохімічні показники крові молодняку свиней за додавання до основного раціону кормових добавок LG-Мах і Сел-Плекс.

Згідно зі схемою дослідження свиням контрольної групи згодовували корми основного раціону, тваринам дослідних груп - різну кількість кормових добавок. Так, групі Д1 до основного раціону згодовували 2,0 г/добу добавки LG-MAX, групі Д2 - 4,0 г/добу добавки LG-MAX, а групі Дз - 2,0 г/добу добавки LG-MAX і Сел-Плекс (0,5 мг/кг) відповідно до реєстраційного посвідчення. У чій статті наведено результати біохімічного дослідження сироватки крові свиней групи Д2 - 4,0 г/добу добавки LG-MAX.

За застосування в годівлі свиней кормової добавки LG-MAX 4,0 г/добу біохімічні показники крові свиней дослідних груп, порівнюючи з контрольною, були у фізіологічних межах, відповідно віку тварин.

Водночас, упродовж періоду дослідження встановили, що біохімічні показники в сироватиі крові дослідної групи свиней порівнюючи з контрольною відповідного віку перебували в такій динаміці: у свиней 45-добового віку достовірно знижується концентрація 8-глобулінів і зменшується вміст аспартатамінотранссрерази, сечовини та фосфрору; у свиней 120-добового віку достовірно підвищується вміст загального білка, концентрації ү-глобулінів і аспартатамінотрансрерази, зменшується вміст альбумінів, глюкози, креатиніну, холестеролу й лужної фосфратази; у свиней 155-добового віку достовірно підвищується концентрація ү-глобулінів і коефіцієнт альбумін/глобулін і збільшується показник вмісту сечовини, кальцію і хлоридів, достовірно меншим був показник вмісту холестеролу та Феруму.

Ключові слова: біохімічні показники, сироватка крові, кормова добавка LG-MAX 